\title{
REPRODUCTION AND GROWTH OF THE TEXAS \\ CORAL SNAKE (MICRURUS FULVIUS TENERE)
}

\author{
By \\ HUBERT RONALD QUINN \\ Bachelor of Science \\ Indiana State University \\ Terre Haute, Indiana
}

1968

\author{
Submitted to the Faculty of the \\ Graduate College of the \\ Oklahoma State University \\ in partial fulfillment of \\ the requirements for \\ the Degree of \\ MASTER OF SCIENCE \\ December, 1977
}




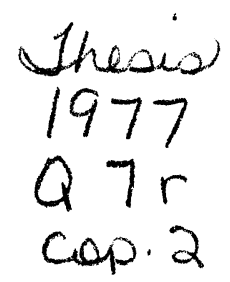


REPRODUCTION AND GROWTH OF THE TEXAS

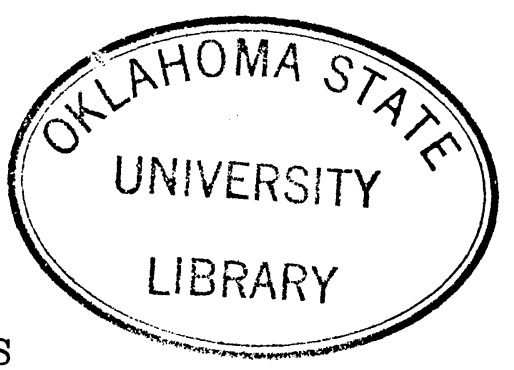

CORAL SNAKE (MICRURUS FULVIUS TENERE)
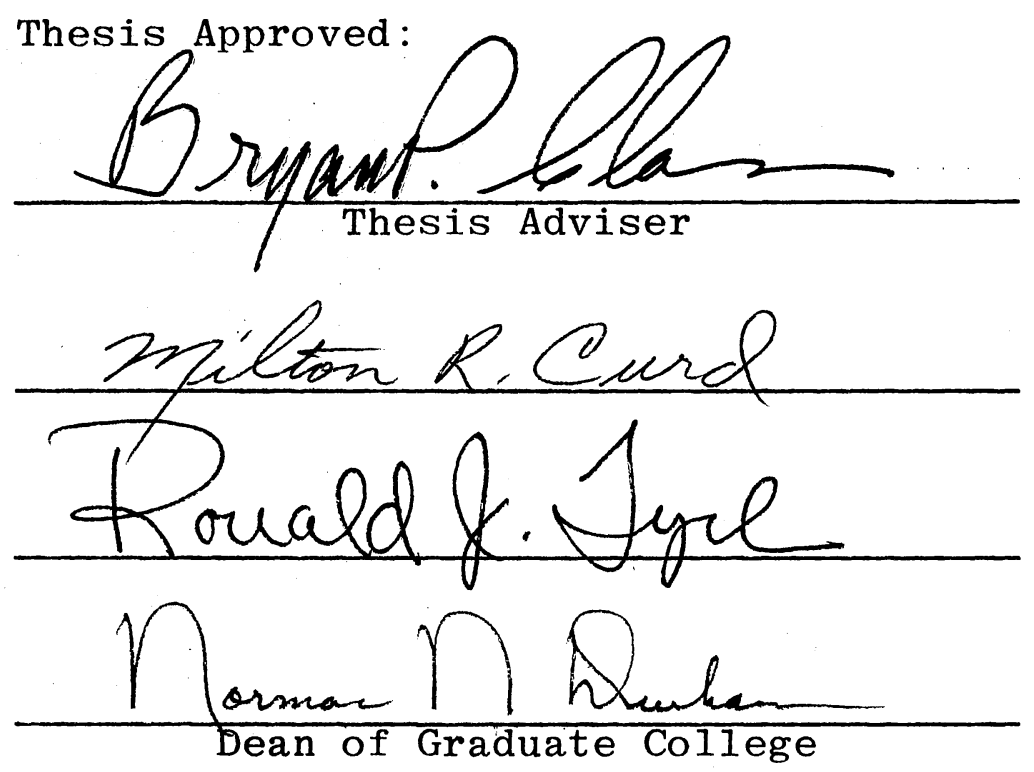

$$
997698
$$


PREFACE

This thesis explores the macroscopic, microscopic and behavioral aspects of reproduction in the coral snake Micrurus fulvius tenere. Preserved specimens were borrowed from museums to investigate the macroscopic and microscopic aspects of their reproductive biology. Several live specimens were maintained to gain insight into their reporductive behavior.

I wish to thank the American Museum of Natural History, Angelo State University, Dallas Museum of Natural History, Fort Worth Museum of Science and History, Louisiana State University in Shreveport, Midwestern State University, Stephen F. Austin University, Sul Ross State University, Texas A\&I University, Texas A\&M University, University of Michigan, University of Texas at Arlington, and University of Texas at Austin for the loan of preserved specimens. I also wish to thank the Dallas, Houston, Lufkin, and San Antonio Zoos and Stephen F. Austin University for donations of live specimens. Gratitude is also extended to Terry G. Hulsey for helping maintain the live specimens and for helping collect data. For guidance in development of my research and for critically reviewing my"thesis, I thank Milton R. Curd, Bryan P. Glass, and Ronald J. Tyrl. Gratitude is extended to Gary W. Ferguson for aid in 
developing my thesis, and to Gary Vinyard for critically reviewing the manuscript. I am grateful to my wife, Gaye, for typing the manuscript. 
TABLE OF CONTENTS

Chapter

Page

I . INTRODUCTION . . . . . . . . . . . . . . . . . 1

II METHODS . . . . . . . . . . . . . . . . . . . 3

III. THE MALE . . . . . . . . . . . . . . . 6

General Reproductive System Morphology . 6

The Reproductive Cycle . . . . . . . . . 7

IV. THE FEMALE . . . . . . . . . . . . . . . 16

General Reproductive System Morphology . 16

The Reproductive Cycle . . . . . . . 17

V. THE REPRODUCTIVE PATTERN . . . . . . . . . . 29

VI. GROWTH AND SIZE AT SEXUAL MATURITY . . . . . . 31

VII. CONCLUSIONS . . . . . . . . . . . . . . . . 34

LITERATURE CITED • . • . . . . . . . . . . . . 36 


\section{LIST OF FIGURES}

Figure

Page

1. Per Cent of Adult Males Undergoing Spermatogenesis During Each Month Where $\mathrm{n}=$ Sample . . . . . . . . . . . . . . . .

2. Mean Seminiferous Tubule Diameter of Adult Males for Each Month Where $\mathrm{n}=$ Sample, $s=$ Standard Error, and $r=$ Range

3. Mean Interstitial Cell Nucleus Size for Adult Males During Each Month Where $\mathrm{n}=$ Sample, $s=$ Standard Error, and $r=$ Range . . . 11

4. Means of the Proportions (Testis Length/ Snake Length) X 100 and (Testis Weight/ Snake Weight) X 1,000 Druing Each Month For Adult Males. $N, S$, and $R$ = Sample, Standard Error, and Range Respectively For Weight Proportions and $n, s$, and $r=$ Sample, Standard Error, and Range Respectively For Length Proportions . . . . . . . . 13

5. Per Cent of Adults With Sperm in Ductus

Deferens and Epididymis. $N$ and $n=$ Sample For Ductus Deferens and Epididymis Respectively . . . . . . . . . . . . . . . . . .

6. Means of the Proportions (Oviduct Weight/

. Snake Weight) X 1,000 and (Ovary Weight/

Snake Weight) X 100 During Each Month For

Adult Females. $N, S$, and $R=$ Sample,

Standard Error, and Range Respectively

For Oviduct Proportions, and $\mathrm{n}, \mathrm{s}$, and $\mathrm{r}=$

Sample, Standard Error, and Range

Respectively For Ovary Proportions . . . . . . . 18

7. Mean Largest Follicle Length in Adult

Females For Each Month Where $\mathrm{n}=1$

Sample, $s=$ Standard Error, and $r=$

Range

8. Per Cent of Adult Females With Sperm in 
Figure

Page

Their Oviducts During Each Month Where

$\mathrm{n}=$ Sample . . . . . . . . . . . . . . 23

9. Means of the Proportions (Fat Body Weight/

Snake Weight) X 100 and (Liver Weight/

Snake Weight) X 100 During Each Month

For Adult Females. $\mathrm{N}, \mathrm{S}$, and $\mathrm{R}=$

Sample, Standard Error, and Range

Respectively For Fat Body Proportions,

and $\mathrm{n}, \mathrm{s}$, and $\mathrm{r}=$ Sample, Standard

Error, and Range Respectively For

Liver Proportions . . . . . . . . . . . . . 28

10. Length Distribution at Each Month.

Zones Indicate Possible Age Groups . . . . . . 33 
CHAPTER I

\section{INTRODUCTION}

Only three accounts have been written concerning reproduction in the Texas coral snake, Micrurus fulvius tenere (Campbe11, 1973; Sabath and Worthington, 1959; Werler, 1951). Telford (1955), Oliver (1955), and Zegel (1975) reported on reproduction in $\underline{M}$. $\underline{f}$ fulvius, while Ditmars (1936), Cochran and Goin (1970), and Schmidt and Davis (1941) examined reproduction in $\underline{M}$. fulvius, but did not specify subspecies. This study was undertaken because only scant information concerning clutch sizes, egg dimensions, incubation periods, hatching dates, copulation dates, and sizes of hatchlings has previously been reported. Specific questions to which answers were sought were (a) times of the year that spermatogenesis occurs, (b) variations in seminiferous tubule diameter in relation to testicular activity, (c) interstitial cell nucleus size variation as related to reproductive activity, (d) times when sperm are stored in the epididymis or ductus deferens, (e) whether the ductus deferens and seminiferous tubule diameters and epithelial heights fluctuate in size through the year and if so whether it is due to packing with sperm or to secretory activity of the cells, (f) the body length 
and time of the year at which males reach sexual maturity, (g) how often and when females lay eggs, (h) the size change in ovarian eggs during the reproductive cycle, (i) the relationship, if any, between fat body weight, liver weight, and the reproductive cycle in females, (j) clutch size and egg dimensions, (k) cyclic oviduct weight changes during the reproductive cycle, which might indicate cellular activity during shell or albumen formation, (1) length and time of the year females reach sexual maturity, (m) description of the reproductive behavior of males and females, and ( $n$ ) growth of $\underline{M} . \underline{f}$. tenere. 


\section{CHAPTER II}

\section{METHODS}

Ninety-three male and 74 female Micrurus fulvius tenere were borrowed from 13 museums and examined in this study. It was presumed the animals were fixed in $10 \%$ formalin and later transferred to alcohol for storage. Some specimens were stored in $40 \%$ isopropanol, some in $60 \%$ isopropanol, and some in $70 \%$ ethanol. Specimens were collected from 1915 through 1975.

Each snake was weighed to the nearest $0.1 \mathrm{~g}$ and by straightening it along a meter stick the snout-vent length was determined to the nearest $\mathrm{mm}$. The right testis of each male was removed and weighed to the nearest $\mathrm{mg}$. An approximate five $\mathrm{mm}$ section of the ductus deferens just posterior to the testis was removed for histological examination. The testis and ductus deferens were embedded in Paraplast and sections cut at $10 \mathrm{\mu m}$. Tissues were stained with Harris' hematoxylin and eosin. Seminiferous tubule diameters, interstitial cell nucleus diameters, epididymis and ductus deferens diameters, and epididymis and ductus deferens epithelial heights were measured with an ocular micrometer. Ten measurements of each parameter were made of each animal. These cross sections that were most nearly 
round were used when measuring the diameters of the seminiferous tubules, epididymis, and ductus deferens. The occurrence of spermatogenesis and presence of sperm in the epididymis and ductus deferens were also noted.

The fat body, liver, right ovary, and right oviduct of each female were removed and weighed to the nearest $\mathrm{mg}$. If oviducal eggs were present, they were removed and the oviduct weighed. Yolked or yolking eggs in each ovary were counted and the length of the largest egg in each ovary was measured to the nearest $0.1 \mathrm{~mm}$. Oviducal eggs were removed from the oviduct, weighed, and their lengths and widths measured to the nearest $0.1 \mathrm{~mm}$. The oviduct was sectioned longitudinally at $10 \mu \mathrm{m}$ and $2-5$ sections containing the lumen were stained with Harris' hematoxylin and eosin.

All histological slides prepared were deposited with the Department of Biological Sciences, Oklahoma State University.

One live male and one live female were used to investigate reproductive behavior and were housed separately in glass enclosures $30 \times 45 \times 30 \mathrm{~cm}$ with gravel substrates, water dishes, and pieces of bark for hiding. They were kept at $20-25^{\circ} \mathrm{C}$ during the day and $17-19^{\circ} \mathrm{C}$ at night for two years prior to their introduction to one another as described later. They were exposed to the photoperiod changes of central Oklahoma. Both snakes were fed two small snakes a week during all months except during winter. 
During winter they were fed one small snake every two weeks. A female obtained five days before she laid eggs was kept in a glass enclosure $61 \times 32 \times 41 \mathrm{~cm}$ at $25^{\circ} \mathrm{C}$. The enclosure contained a paper substrate, cloth rags for hiding, and a water dish. The female did not feed before laying eggs. 


\section{CHAPTER III}

\section{THE MALE}

\section{A. General Reproductive System Morphology}

The middle of the left testis of $\underline{M}$. $\underline{f}$ tenere lies about $33 \%$ of the body length anterior to the cloaca, with the right testis completely anterior to the left. The testis contains a coiled mass of seminiferous tubules surrounded by a connective tissue tunica albuginea. Connective tissue septa from the tunica albuginea occur between the tubules, and the interstitial tissue contains interstitial cells, blood vessels, and fibroblasts. The seminiferous tubules empty into the ductuli efferentes which transport sperm to the epididymis. No rete tubules are present in $\underline{M}$. $\underline{f}$. tenere, which supports the absence of rete tubules in all snakes as proposed by Fox (1952). The epididymis empties into the ductus deferens which transports sperm to the cloaca. The epithelium of the ductuli efferentes is cuboidal to low cuboidal, while the epithelium of the epididymis is pseudostratified to high columnar without stereocilia. The ductus deferens epithelium varies from columnar to low columnar. 


\section{B. The Reproductive Cycle}

Spermatogenesis was not found to occur during July, but did occur during all other months (Fig. 1). The July sample was small $(n+3)$, and one specimen may not have reached sexual maturity, as it was only $42.1 \mathrm{~cm}$ in length (See the section on growth and size at sexual maturity) (Fig. 10). Also, more individuals were found in each May, June, and August not undergoing spermatogenesis than in July. While the above may add uncertainty to quiescence in the testis of all males in July, the sharp decline in the percentage of males undergoing spermatogenesis from April through June indicates a definite decline in spermatogenic activity. This decline may terminate in complete quiescence of all males in July. The apparent decline in percentage of males undergoing spermatogenesis in November may reflect the small sample size $(n=3)$. Also, one of the males may not have been sexually mature, as it was only $40.0 \mathrm{~cm}$ in length, the minimum adult size (See the section on growth and size at sexual maturity). October had an adequate sample $(n=8)$, but two specimens not undergoing spermatogenesis were 41.5 and $40.0 \mathrm{~cm}$ in length, near the minimum adult size. If these individuals were immature, this would make the per cent of adults undergoing spermatogenesis in October even higher. This indicates that the percentage of males undergoing spermatogenesis in November may be considerably higher than the data indicate 


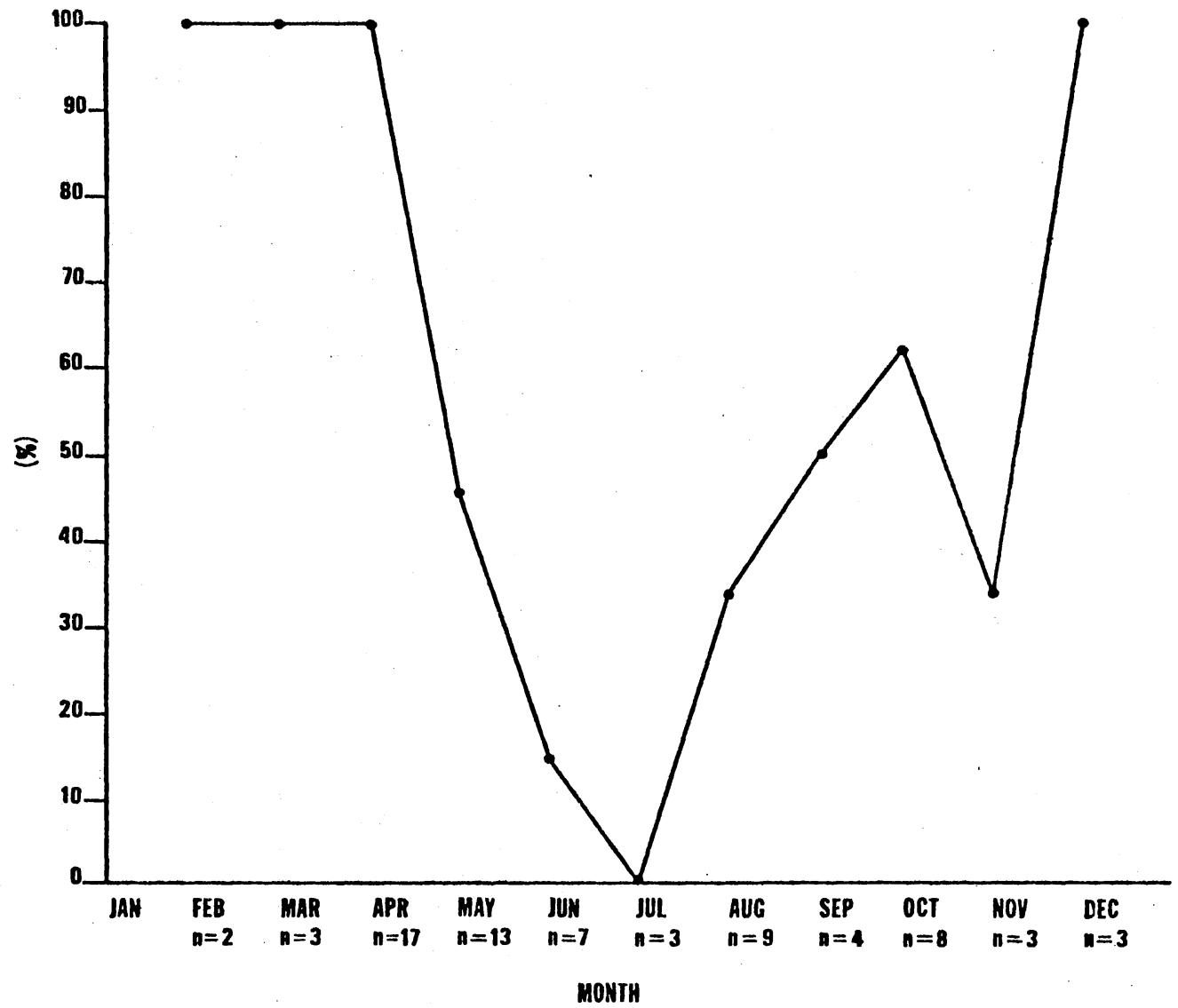

Figure 1. Per Cent of Adult Males Undergoing Spermatogenesis During Each Month Where $\mathrm{n}=$ Sample. 
if the percentage increases each month from July to December. The seminiferous tubule diameter roughly followed the relationship shown in Figure 1 indicating regression of the testis during June (Fig. 2).

Interstitial cell nucleus size has been reported to increase with cell activity and has been related to the onset of either sperm production, breeding, or both in certain reptiles (Blount, 1929; Cieslak, 1945; Goldberg and Parker, 1975; Lofts et a1, 1966; Reynolds, 1943; Vols $\phi$ e, 1944 ; and more). However, in Sternotherus odoratus (Risley, 1938) and in Xantusia vigilis (Miller, 1948), no seasonal variation in interstitial cell size was detected, and in agreement with these, no correlation was found between reproductive activity and interstitial cell nucleus size in $\underline{\text {. }}$. tenere (Fig. 3). If the small. samples in February, March, September, November, and December caused the mean interstitial cell nucleus size to be smaller than if a larger sample was taken, a curve with a low point in June might result. This would be similar to the curve in Figure 2 , indicating reduced reproductive activity in June. Because the above five months collectively represent a sample of 13 males (Fig. 3), it seems unlikely that a decrease in mean interstitial cell nucleus size with a curve low point in June would occur. By using the relationships (testis length/snout-vent length) X 100 and (testis weight/snake weight) X 1,000 as indicators of testicular activity, a decline in activity 


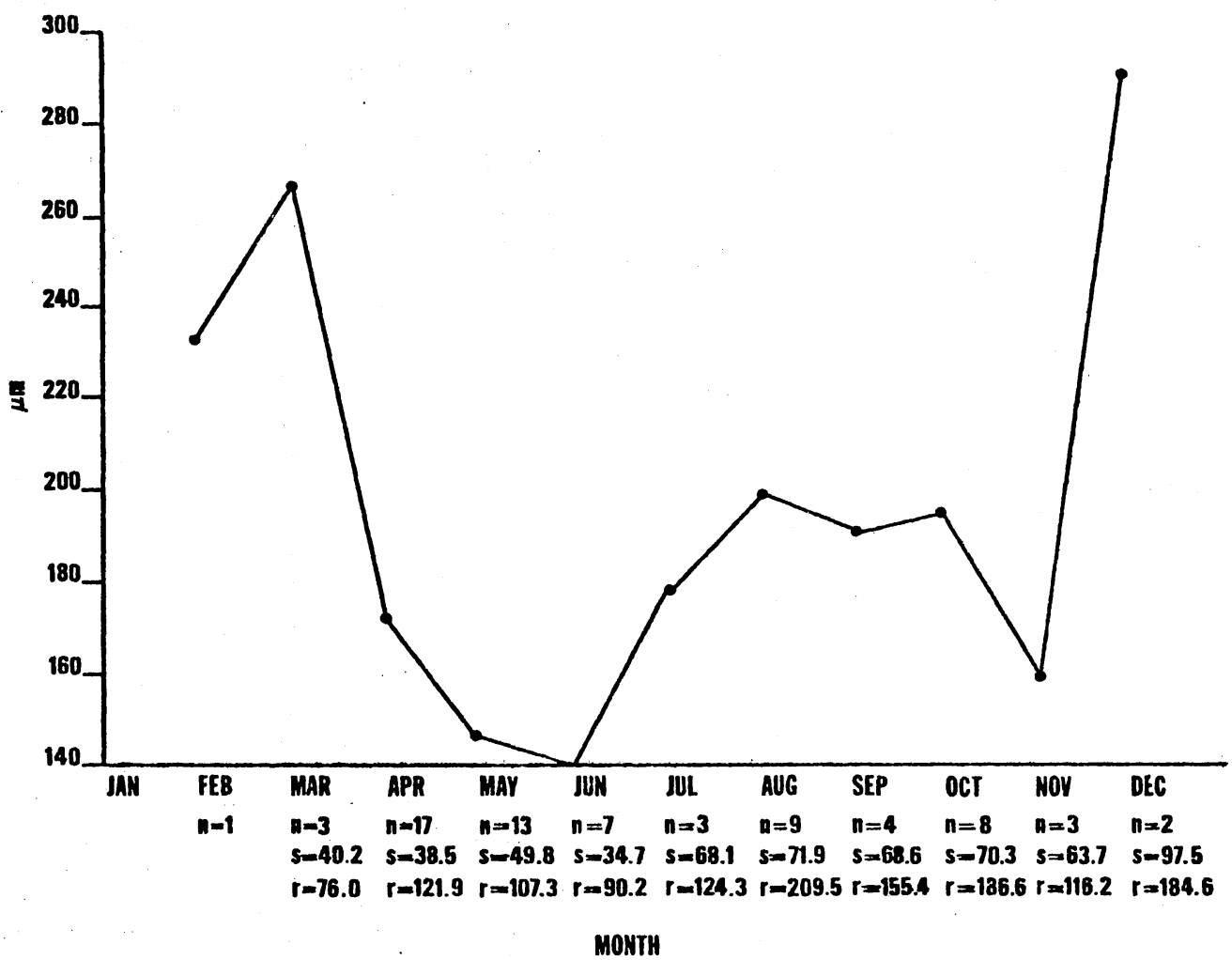

Figure 2. Mean Seminiferous Tubule Diameter of Adult Males for Each Month Where $n=$ Sample, $s=$ Standard Error, and $r=$ Range. 


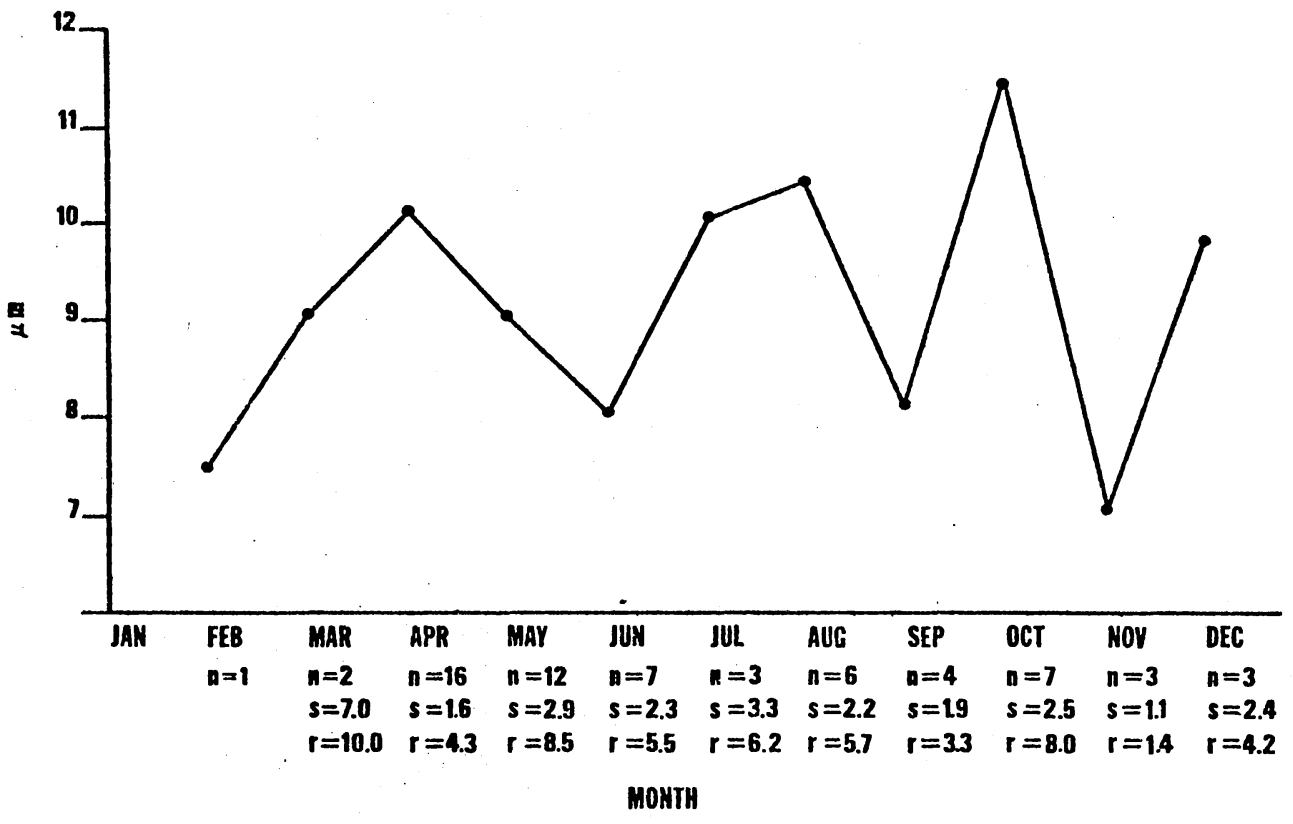

Figure 3. Mean Interstitial Cell Nucleus Size for Adult Males During Each Month Where $\mathrm{n}=$ Sample, $s=$ Standard Error, and $r=$ Range. 
through the spring with a minimum in August was seen (Fig. 4). Activity increased in the fall and maintined a high level through the winter. The reduced length ratio in February may have been due to a small sample $(n=2)$. Specimens may change length and weight according to how long they have been preserved and according to the method of preservation. The method of preservation may also affect measuring the length of specimens in that some straighten along the meter stick more completely than others. All of the above plus small samples during some months introduce error into Figure 4.

The only month sperm were not found in the ductus deferens was July (Fig. 5). Sperm were present in the epididymis in all months except July and November. The absence of sperm in November may again have resulted from a small sample $(n=2)$ including the possibly immature individual described earlier. Samples were small for most months, however, introducing uncertainty into interpretation of Figure 5 .

Since sperm were not being produced in July, but were being produced the rest of the year (Fig. 1), and since sperm were not present in the epididymis and ductus deferens during July, but were present the rest of the year (with the exception mentioned above) (Fig. 5), then sperm were probably stored in the males no longer than 10 months. Since sperm were continuously being produced during all months except July (Fig. 1), then they may have been 


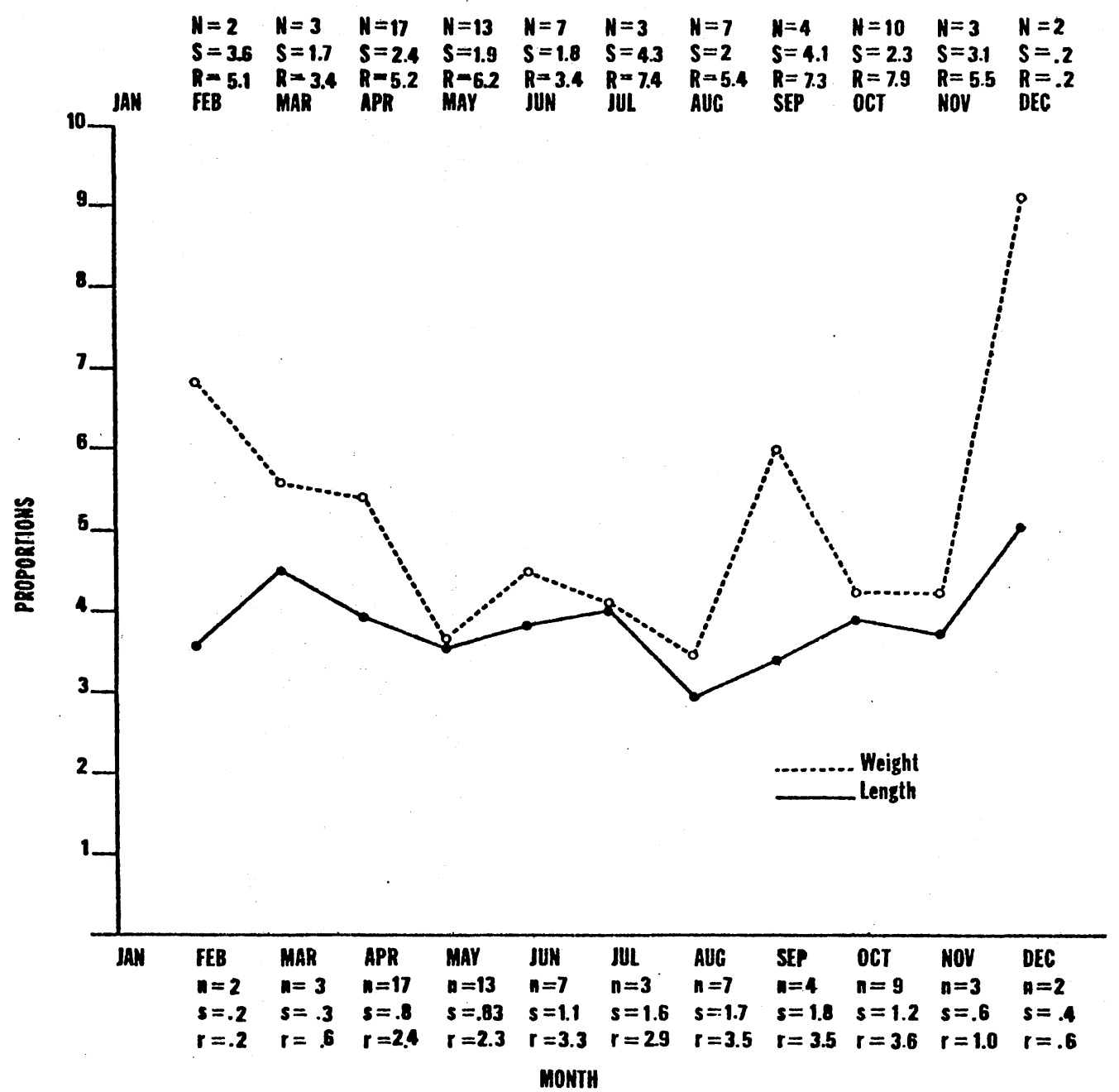

Figure 4. Means of the Proportions (Testis Length/ Snake Length) X 100 and (Testis Weight/ Snake Weight) X 1,000 During Each Month For Adult Males. $\mathrm{N}, \mathrm{S}$, and $\mathrm{R}=$ Sample, Standard Error and Range Respectively For Weight Proportions and $n, s$, and $r=$ Sample, Standard Error, and Range Respectively For Length Proportions. 


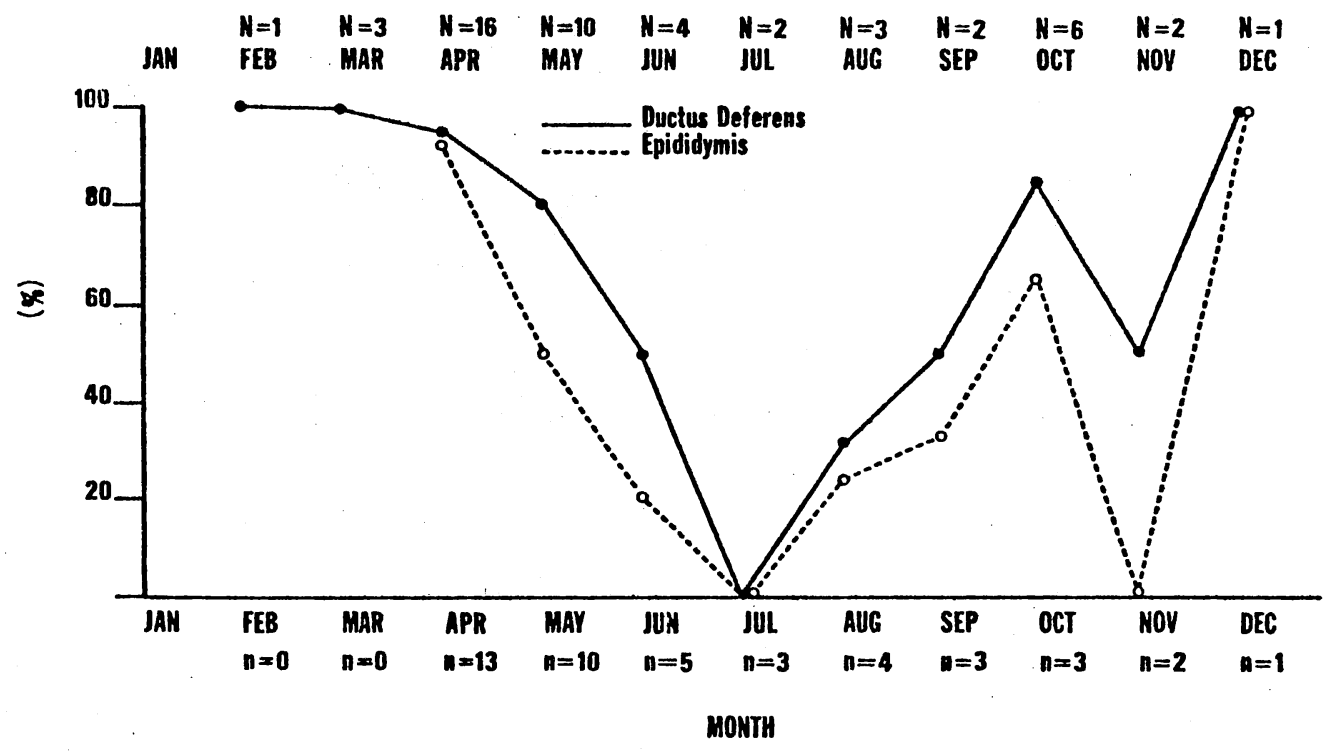

Figure 5. Per Cent of Adults With Sperm in Ductus Deferens and Epididymis. $\mathrm{N}$ and $\mathrm{n}=$ Sample For Ductus Deferens and Epididymis Respectively. 
stored for much less than 10 months.

The diameters of the ductus deferens and epididymis without sperm $(\bar{X}=147.53 \pm 21.79,134.62 \pm 21.92 \mu \mathrm{m})$ were significantly smaller $(P<.001)$ than those containing sperm $(\bar{X}=287.16 \pm 12.77,236.86 \pm 13.29 \mu \mathrm{m})$. Epithelial height of the ductus deferens was not significantly different $(P>.4)$ when it contained sperm $(\bar{X}=24.59 \pm$ $2.04 \mu \mathrm{m})$ as compared to when it did not $(\bar{X}=20.60 \pm 2.69$ um). The epithelial height of the epididymis was, however, significantly higher $(\mathrm{P}<.01)$ when it contained sperm $(\bar{X}=29.92 \pm 1.81 \mathrm{\mu m})$ than it did not $(\bar{X}=21.29 \pm 1.87 \mathrm{\mu m})$. An increase in epithelial height when sperm were present indicates increased cellular activity and suggests that the epididymis may have been secreting nourishment for sperm (Fox, 1952; Lofts, 1966). Because there was no indication of epithelial height change in the ductus deferens, the increase in tubule diameter seems to have been due to expansion from packing with sperm. The expansion of the epididymis when sperm were present may have been due in part to increased epithelial height and in part to packing with sperm. Since the ductus deferens diameter, epididymis diameter, and epididymis epithelial height all increased with the presence of sperm, and since the percentage of males with sperm in the ductus deferens and epididymis was cyclic during the year (Fig. 5), then the tubule diameters and epididymis epithelial height must also have reflected a cyclic change. 


\section{CHAPTER IV}

\section{THE FEMALE}

\section{A. General Reproductive System Morphology}

The middle of the left ovary of $M$. f. tenere lies about $33 \%$ of the body length anterior to the cloaca, with the posterior end immediately anterior to the left kidney. The ovaries usually overlap one another about $10 \%$ of their lengths. The anterior end of the right ovary is situated posteriorly about $50-75 \%$ of the body length, depending somewhat on the size of the ovary. Each ovary is suspended by a mesovarium into the pleuroperitoneal cavity between the dorsal mesentery and the mesotubarium.

The most distal segment of the oviduct consists of a thick-walled, bulbous vaginal pouch which empties into the cloaca. Anterior to the vaginal pouch is the vagina and anterior to the vagina is the long, straight-tubed uterus. The posterior end of the uterus is about $25 \%$ of the distance from the cloaca to the posterior margin of the kidney. Anteriorly, the uterus joins the convoluted tuba just posterior to the ovary. The tuba extends to the middle of the ovary where the thin walled infundibulum begins. The infundibulum terminates slightly anterior to the ovary.

The posterior end of the fat bodies is located just 
anterior to the kidneys, with occasional patches of fat lateral to the midsection of each kidney. The fat bodies are positioned ventral and sometimes lateral to the intestine and extend anteriorly to the posterior tip of the liver about at mid-length of the snake. The liver extends forward to the heart which is located at a point about $25 \%$ of the snake's length behind its head.

\section{B. The Reproductive Cycle}

Ovary weights of $\underline{M}$. $\underline{f}$ tenere increased from March through April indicating follicular growth. Ovary weights declined slightly in May, then dropped rapidly in June (Fig. 6). Follicle lengths showed the same pattern as ovary weights; increasing in size in March and reaching their maximum sizes in April. They dropped slightly in May, then rapidly in June (Fig. 7). The changes in ovary weight and follicle length indicated that most did so in June. Zegel (1975) and Telford (1955) reported egg laying in $\underline{M}$. $\underline{\text { fulvius }}$ on 6 July and 18 June respectively. Oliver (1955) stated that eggs of $\underline{M}$. $\underline{f}$ fulvius are laid in May and June, while Ditmars (1936) reported that a $\underline{M}$. fulvius laid eggs on 29 June, but did not specify subspecies.

A female M. f. tenere $59.6 \mathrm{~cm}$ in length and $33.3 \mathrm{~g}$ in weight was received from the Houston Zoo 5 June 1974. Although collection data were not available, it was presumed that the snake was collected in or near Harris 


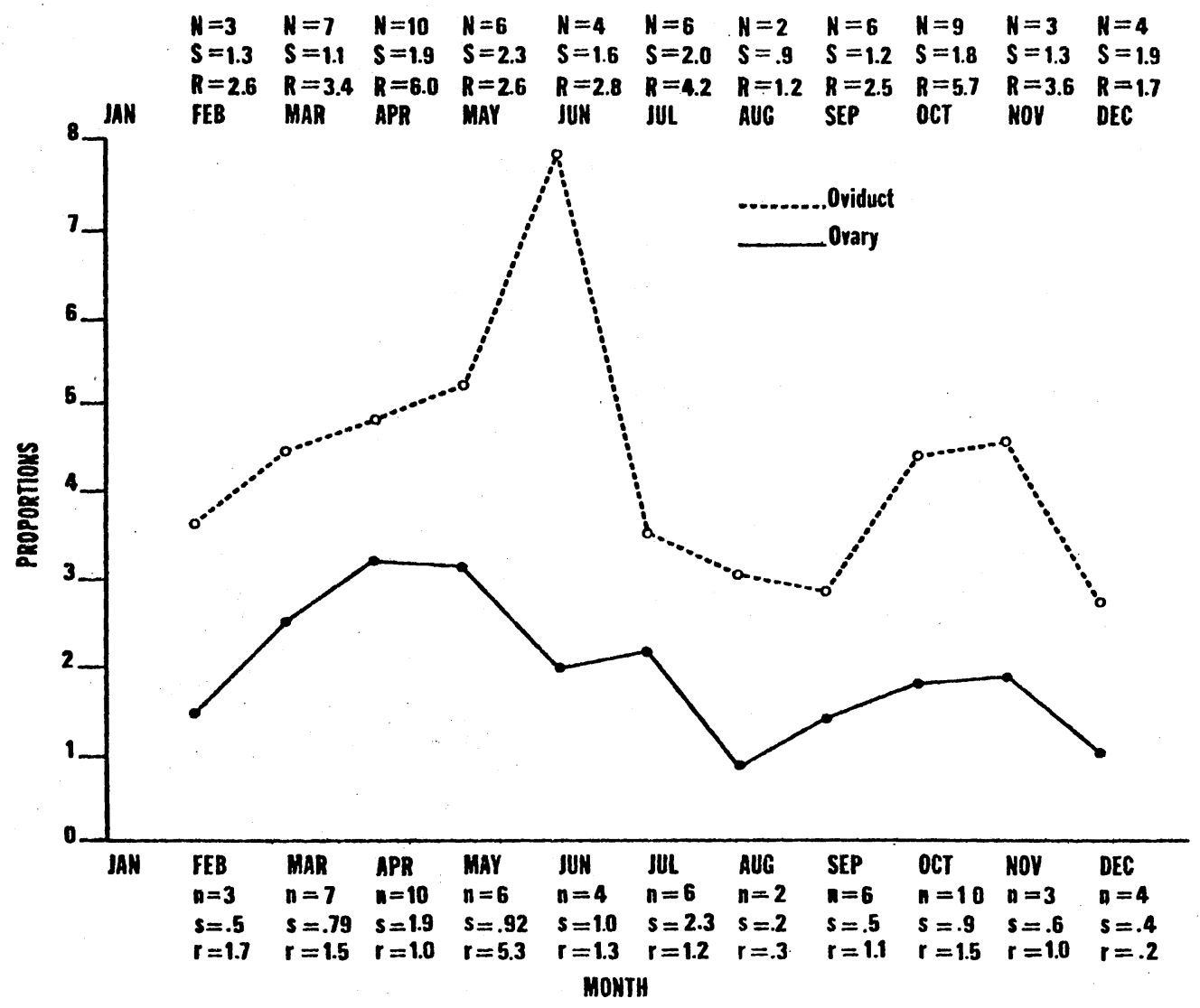

Figure 6. Means of the Proportions (Oviduct Weight/ Snake Weight) X 1,000 and (Ovary Weight/ Snake Weight X 100 During Each Month For Adult Females. $\mathrm{N}, \mathrm{S}$, and $\mathrm{R}=$ Sample, Standard Error, and Range Respectively For Oviduct Proportions, and $\mathrm{n}, \mathrm{s}$, and $\mathrm{r}=$ Sample, Standard Error, and Range Respectively For Ovary Proportions. 


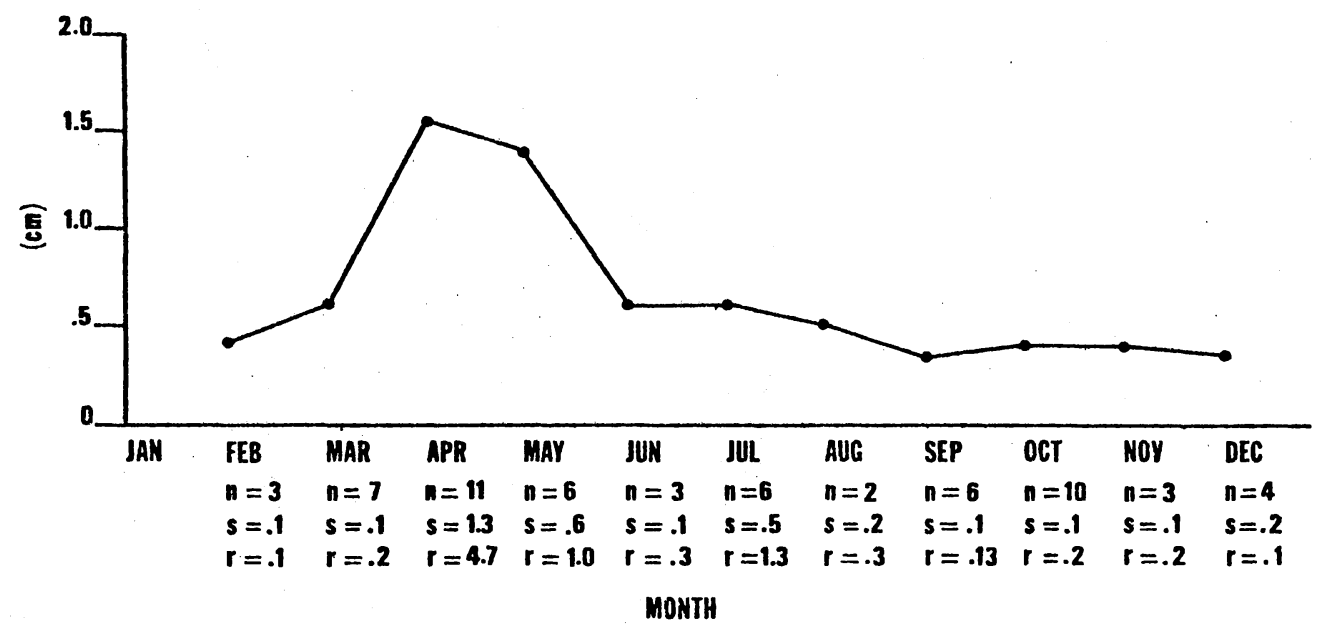

Figure 7. Mean Largest Follicle Length in Adult Females For Each Month Where $\mathrm{n}=$ Sample, $s=$ Standard Error, and $r=$ Range. 
County, Texas. The snake was kept as described in the methods section. At $0845 \mathrm{~h}$ on 10 June 1974 two eggs were observed in the enclosure. The last time the snake was observed before egg laying was $2330 \mathrm{~h}$ on 9 June. The eggs were found in an area of the enclosure that had no cloth rags. The female was $2-3 \mathrm{~cm}$ from the eggs, and there was no indication of egg guarding as described by Campbell (1973). The eggs were removed from the enclosure and incubated in the manner described by Campbell (1972). A hiding box $20 \times 20 \times 10 \mathrm{~cm}$ was placed in the enclosure and filled with moist shredded paper with hopes that guarding behavior might be observed. The snake was placed in the box at $0829 \mathrm{~h}$ on 10 June. The enclosure was inspected for eggs at $1005 \mathrm{~h}$, but no eggs were found and the female was no longer in the nest box. A third egg was discovered at $1402 \mathrm{~h}$ at the opposite end of the enclosure from where the other two were found. The female was touching the egg, but was not coiled around it. The egg was removed and incubated in the same manner as described above, but none developed embryos and were presumed to be infertile. Of the snakes examined only two females were found with eggs in their oviducts, having been collected 3 and 8 June. The mean lengths and diameters of these oviducal eggs were $3.21 \times .97$ and $3.34 \times 1.15 \mathrm{~cm}$ respectively. Werler (1951) examined a $\underline{M} \cdot \underline{f} \cdot \underline{\text { tenere }} 3$ June and found eggs of mean dimensions $1.54 \times 1.06 \mathrm{~cm}$, while Sabath and Worthington (1959) dissected a female 5 May and discovered 
eggs $2.0-2.3 \mathrm{~cm}$ long and $.60-.70 \mathrm{~cm}$ wide. The mean dimensions of the eggs laid by my live female were $4.0 \mathrm{X}$ $2.5 \mathrm{~cm}$, while those reported for $\underline{M}$. $\underline{\text { f }}$ fulvius were $4.14 \mathrm{X}$ $1.21 \mathrm{~cm}$ (Zegel, 1975), and $3.88 \times 1.37 \mathrm{~cm}$ (Telford, 1955). Egg dimensions reported by Campbel1 (1973) were $4.60 \mathrm{X}$ $1.35 \mathrm{~cm}$, but his measurements were taken approximately five weeks after the eggs were laid. Since $\underline{M}$. $\underline{f}$ fulvius eggs increase in size as they incubate (Zegel, 1975), Campbell's eggs were larger when measured than when laid.

Campbel1 (1973) reported a clutch size of four for $\underline{M}$. f. tenere, while Werler (1951) and Sabath and Worthington (1959) reported clutch sizes of nine and seven respectfully for snakes they dissected. Zegel (1975) reported a clutch size of five, Oliver (1955) 2-4, and Telford (1955) seven for $\underline{\text { M. }}$ f fulvius. Ditmars (1936) and Cochran and Goin reported a clutch size of seven and 3-12 respectively, but did not identify subspecies. Schmidt and Davis (1941) stated that two to four eggs are produced as indicated by females ready for oviposition, but also did not specify subspecies. The live female reported here laid three eggs. One of the two specimens found in this study with oviducal eggs contained five in the right oviduct and two in the left, while the other specimen contained three eggs in each oviduct. The mean number of eggs in the right ovary for females collected in April and May was 5.8, while the mean for the left ovary was 4.8. Since the right oviduct is longer than the left, it is reasonable that more eggs may 
be ovulated from the right ovary. Oviducal weight increased during the spring and reached a maximum in June (Fig. 6). This increase in weight was probably due to increased oviducal cellular activity in preparation for egg shell or albumin formation. There was a sharp decline in oviduct weight in July after egg laying.

Telford (1955) stated that Ditmars (1936) gave 49 days as an incubation period for $\underline{M}$. fulvius eggs. However, Ditmars (1936) gave from 29 June to 26 and 28 September, a period of 90 and 92 days, as the incubation period, but did not indicate subspecies. Zegel (1975) reported an incubation period of 47 days for $\underline{M}$. $\underline{f}$ fulvius.

Sperm were found in the oviducts of females from October through May (Fig. 8). This indicates that copulation may occur throughout this period and that the females may have the capability to store sperm for a period of up to seven months. It also indicates extended sperm production in males. Sperm storage would be of advantage if: (1) coral snakes were rare in certain areas, resulting in few encounters between sexes; (2) many encounters resulted in agressive biting as displayed by the pair of newlyintroduced snakes described later; (3) males had difficulty in locating females due to weak sensory perception or inadequate pheromone production by females, resulting in few encounters; or (4) coral snakes had small home ranges, thus seldom encountering one another. Any or all of the above factors could be reasons for the type of breeding 


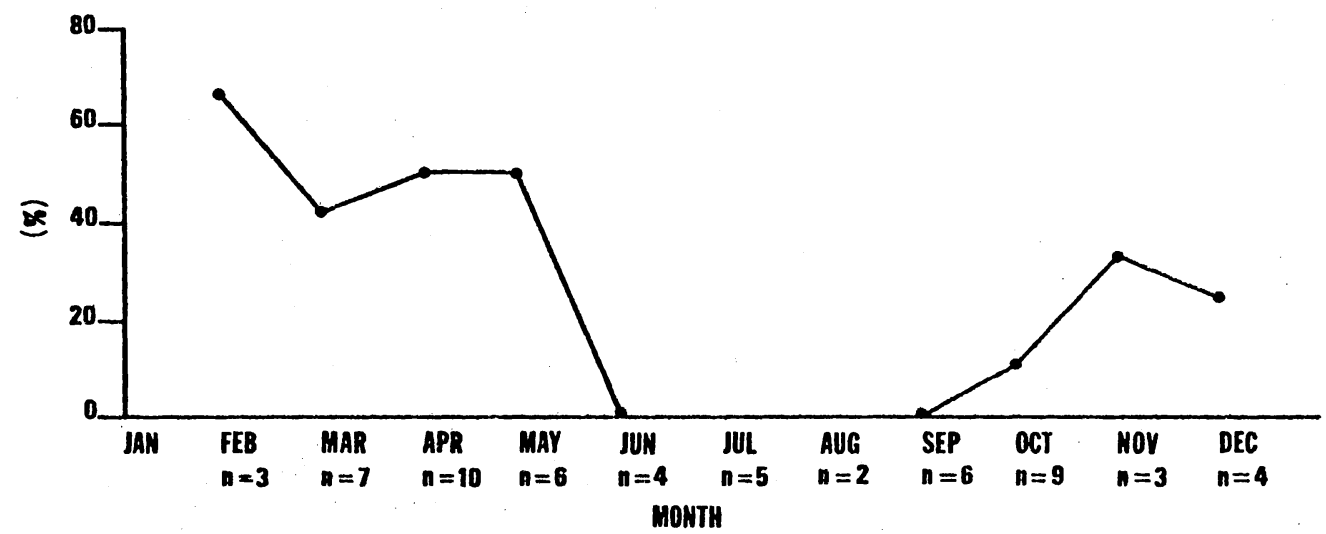

Figure 8. Per Cent of Adult Females With Sperm in Their Oviducts During Each Month Where $\mathrm{n}=$ Sample. 
pattern here described for $\underline{M}$. $\underline{f}$. tenere.

Werler (1951) reported copulation in captive $\underline{M} \cdot \underline{f}$. tenere on 16 and 18 May, but did not note any copulatory behavior. Zegel (1975) noted that his pair of $\underline{M}$. $\underline{f}$. fulvius made jerking motions and that the male followed the female and rubbed his chin over her back, but never observed copulation. On 16 April 1977 a female collected sometime in June 1975 probably from Harris County, Texas, was paired with a male collected 13 June 1975 from Nacogdoches County, Texas. The male was $55.1 \mathrm{~cm}$ in length and weighed $30.1 \mathrm{~g}$, while the female was $59.6 \mathrm{~cm}$ in length and weighed $33.3 \mathrm{~g}$. She was placed at the opposite end of the male's enclosure from him, but immediately rushed to the male when he moved. The female bit and held the male at mid body as if to eat him. She maintained her hold for about two seconds, then released the thrashing male. They were left together for approximately 0.5 hours and each time they came in contact the male bolted away. On 18 April the female was again introduced to the male. The male immediately crawled to the female and flicked his tongute several times on her back at mid body. He then raised his head and neck at about a $45^{\circ}$ angle and, leaving his neck at that angle, tilted his head down and touched his nose to the female's back. In this position he quickly and smoothly ran his nose along the dorsum of the female to about two inches behind her head. No tongue flicks from the male were seen during this advance, but during this time he aligned his body over hers. He 
dipped his body and tail at his vent region laterally on the female's right side beside her vent. Immediately anterior to the vent the male's body was at the female's dorsum and immediately posterior to the vent his tail projected upward at about a $30^{\circ}$ angle, not touching the female's tail. Her tail rested flat on the substrate. Several vent thrusts were made by the male in an attempt to copulate and his hemipenes occasionally partially everted. The female did not gape her vent and darted away. The male pursued the female and the sequence was repeated. This occurred five times in 40 minutes, after which the snakes were separated. Sixty per cent of the time the male moved along the female's dorsum from rear to front. Forty per cent of the time he went the other direction, and when he reached the area of the female's vent he quickly turned anteriorly without removing his nose from her body and progressed toward her head.

On 18 and 21 April the female was again introduced to the male with a repeat of the behavior described above. On 21 April, however, after the male had unsuccessfully attempted intromission, he moved his entire body back and forth at about $2.5 \mathrm{~cm}$ strokes on the female's dorsum. He completed five of these strokes in about five seconds, with the sequence ending in several rapid strokes of his nose only. His nose strokes were about $1.25 \mathrm{~cm}$ and were made at a speed of about two per second. Nothing further transpired. On 28 April and 10 May the snakes were again placed to- 
gether, but the male showed no interest in the female, even when on 10 May the female held her tail at about a $30^{\circ}$ angle and gaped her vent during the entire period they were together. Motor patterns not observed in $\underline{M} . \underline{f}$. tenere that were observed in Elaphe as described by Gillingham (1976) were forward-jerking, writhe-bumping, intromission, and body-bridging.

The relation between fat and the reproductive cycles of reptiles has been discussed by several authors. Vols $\phi$ e (1944) stated that fat bodies contributed to the growth of eggs during pregnancy. Tinkle (1962) showed that fat weight for adult reproductive and non-reproductive female Crotalus atrox in Texas were $11.7 \%$ and $7.9 \%$ snake weight respectively. Wharton (1966) suggested that food consumed could supplement fat reserves for yolk formation in Agkistrodon piscivorus in Florida. This suggests that snakes which have abundant food during yolk formation might have fat cycles that are independent of their reproductive cycle. In $\underline{M}$. $\underline{f}$. tenere there was an inverse relationship between fat weight changes and ovary weight changes in the spring (Figs. 6 and 9). This suggests that fat is used in egg development and that a lower percentage of fat is needed for $\underline{M}$. $\underline{f}$. tenere to reproduce than $\underline{\text { C. }}$ atrox $(T i n k l e, 1962)$. Fat weight increased from June to August, dropped from August to September, then increased again from September through December. The August peak may be due to a small sample size $(n=2)$. If a larger sample was obtained, this peak may have been 
lowered, eliminating a decrease in fat body weight from August to September. Three explanations given for fat increases in lizards are: (1) an increase in available food, (2) an increase in appetite, and (3) a decrease in energy expenditure leading to storage of assimilated energy (Licht and Gorman, 1970). Any or all of these reasons could cause the increase in fat weight in $\underline{M}$. $\underline{f}$. tenere in the fall and winter.

It has been postulated that liver fat in reptiles may constitute fat stored for energy, fat intake from the gut, and movement of fat from one part of the body to another (Jameson, 1974). Jameson (1974) showed that as fat bodies decreased in size in Sceloporus graciosus, liver fat content increased. No relation was found between liver weight cycles and fat body cycles in female M. 卢. tenere (Fig. 9). 


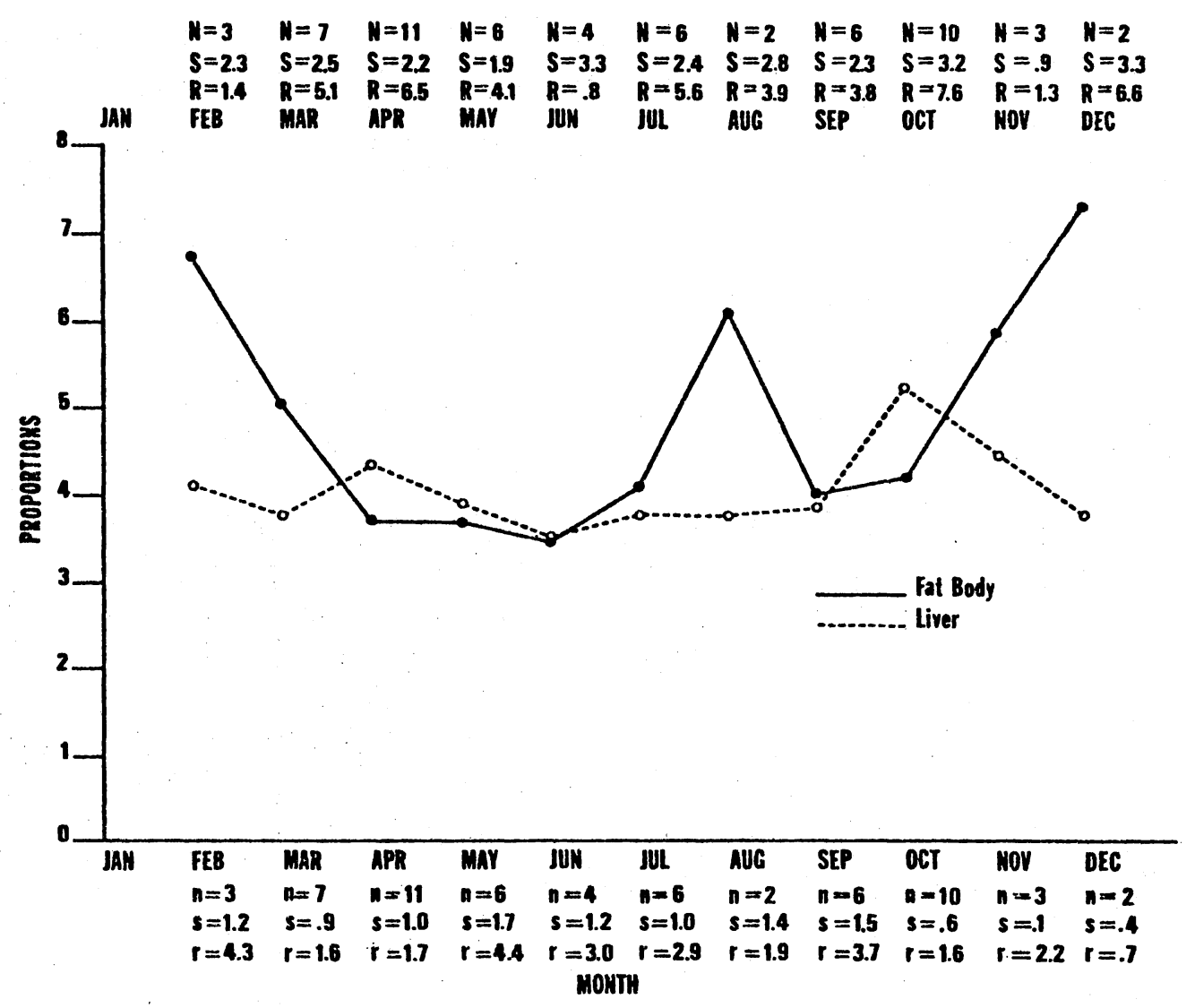

Figure 9. Means of the Proportions (Fat Body Weight/

Snake Weight) X 100 and (Liver Weight/

Snake Weight) X 100 During Each Month

For Adult Females. $\mathrm{N}, \mathrm{S}$, and $\mathrm{R}=$

Sample, Standard Error, and Range

Respectively For Fat Body Proportions, and $n, s$, and $r=$ Sample, Standard

Error, and Range Respectively For

Liver Proportions. 
CHAPTER V

THE REPRODUCTIVE PATTERN

Many species of North American snakes undergo spermatogenesis during late summer and early autumn. They store sperm through the winter and copulate the following spring and early summer (Cieslak, 1945; Fitch, 1963; Fox, 1952; Goldberg and Parker, 1975; Myers, 1965; Platt, 1969; and more). This pattern of reproduction was termed post-nuptial by Volsфe (1944). Snakes such as Diadophis punctatus (Fitch, 1970) and Carphophis vermis (Clark, 1964) have bimodal breeding patterns, copulating both in autumn and spring. No other North American snake has been reported to breed from late summer and early autumn to late spring and early summer, then lay its eggs in mid-summer as does $\underline{M}$. fulvius. This type of breeding is here termed midaestivoquiescent. While specimens in the northern portion of the coral snake's range may hibernate and thus not breed during the winter months, specimens have been caputred in November and December as far north as Nacogdoches County, Texas, and in February as far north as Kenedy County, Texas. This indicates that these snakes were possibly active and since the males were undergoing spermatogenesis (Fig. 1) and the females were found to con- 
tain sperm in their oviducts (Fig. 8), some snakes probably breed in winter. 
CHAPTER VI

GROWTH AND SIZE AT SEXUAL MATURITY

The lengths of hatchling $\underline{M}$. $\underline{f}$. tenere have been recorded as $20.5 \mathrm{~cm}$ and $20.0 \mathrm{~cm}$ (Campbell, 1973). A mean length of $18.5 \mathrm{~cm}$ was reported for five hatchling $\underline{M} . \underline{f}$. fulvius (Zegel, 1975). Ditmars (1936) recorded hatchling lengths of 19.7 and $17.8 \mathrm{~cm}$, but did not specify subspecies. Hatchling dates of the above were 1 September (Campbell, 1973), 22 and 23 August (Zegel, 1975), and 26 and 28 September (Ditmars, 1936). Of the snakes examined the smallest was a $21.1 \mathrm{~cm}$ male collected 28 August. No growth data are available for $\underline{M}$. fulvius from specimens marked and recaptured or raised in captivity. By knowing the size of hatchling $\underline{M}$. fulvius and by searching for size groups within a given month, arbitrary growth zones were drawn on Figure 10, illustrating probable year classes. Zone 1 illustrates growth from hatching in August or September through December of the same year. Zone 2 illustrates growth during the next calendar year, and zone 3 shows a size distribution for the following years. The first 10 months have rather well defined size groups making the animal's size an accurate estimate of age. After 10 months, 
however, the ages of individuals near the upper limit of zone 2 cannot be determined with certainty.

From the data available it could not be determined if growth rates were different between the sexes, but the largenst male measured $68.5 \mathrm{~cm}$ in length, while 15 females were over that length (Fig. 10), suggesting that females reach a maximum length longer than that of males. The largest female measured was $97.1 \mathrm{~cm}$, but the record for $\underline{M}$. f. tenere was reported as $112.4 \mathrm{~cm}$ (Conant, 1975). The sex of the record length individual was not noted.

Wright and Wright (1957) stated that the minimum length for adult $\underline{M}$. $\underline{f}$ tenere is $43.18 \mathrm{~cm}$. The smallest male found undergoing spermatogenesis was $40.2 \mathrm{~cm}$ in length and was collected in April. Also collected in April was a male 39.8 $\mathrm{cm}$ in length that was not undergoing spermatogenesis. All snakes over $40 \mathrm{~cm}$ in length in April $(\mathrm{n}=16)$ were undergoing spermatogenesis, while all under $40 \mathrm{~cm}(\mathrm{n}=5)$ were not. Using $40 \mathrm{~cm}$ as the assumed length for sexual maturity, male coral snakes seem to mature at $12-21$ months of age (Fig. 10).

The smallest female found to contain sperm in the oviduct was $49.4 \mathrm{~cm}$ in length and was collected in December. Her age estimated from length was approximately 15 months (Fig. 10). This suggests that females may first lay eggs at an age of about 21 months and at a minimum length of about $55 \mathrm{~cm}$ (Fig. 10). 


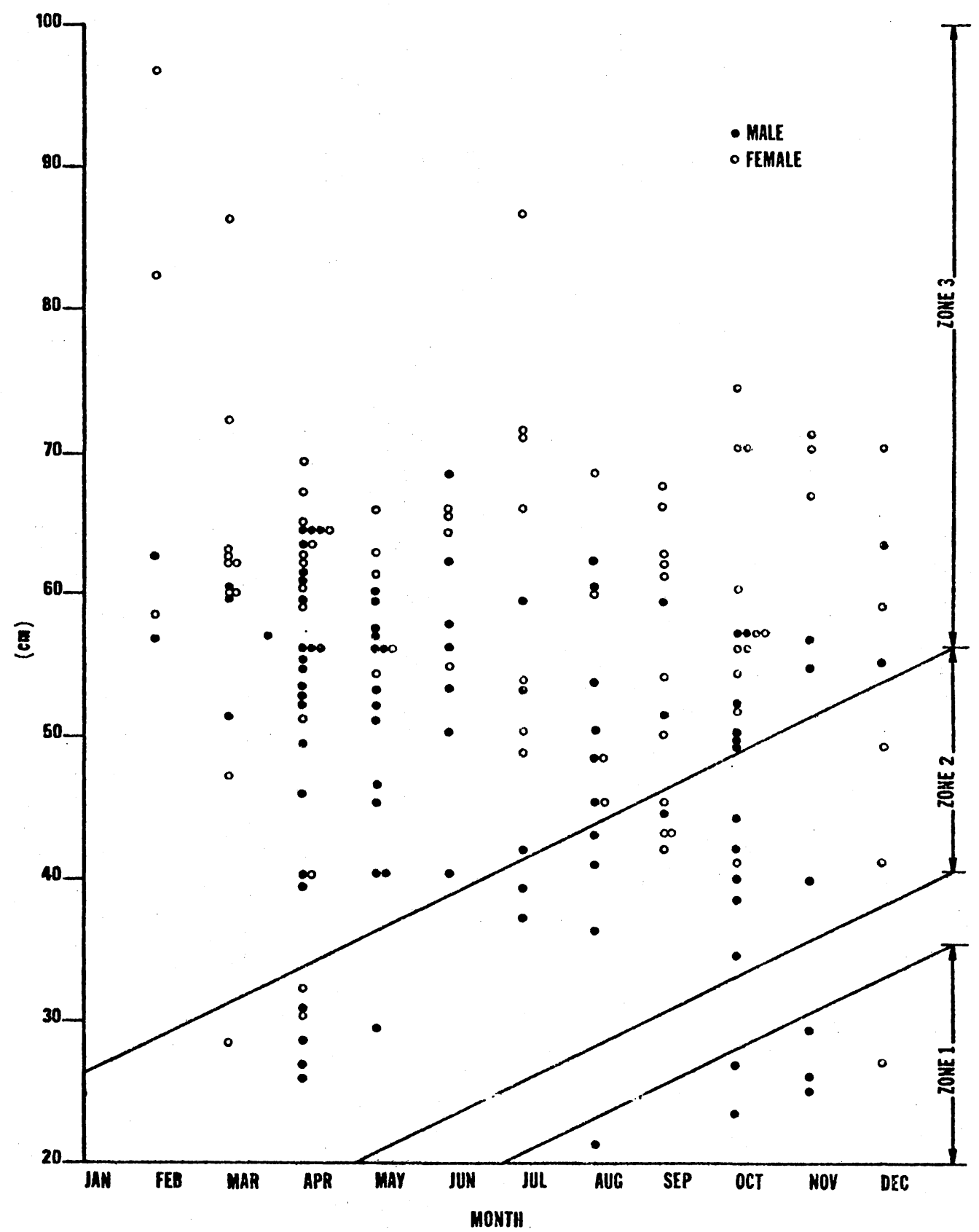

Figure 10. Length Distribution at Each Month. Zones Indicate Possible Age Groups. 
CHAPTER VII

CONCLUSIONS

Spermatogenesis occurs in all months except July in Micrurus fulvius tenere. Seminiferous tubule diameters were smallest in June. No correlation was found between reproductive activity and interstitial cell nucleus size. Sperm were not found in the epididymis or ductus deferens when spermatogenesis was not occurring, indicating that sperm are stored in the male no longer than 10 months. The sperm may be nourished by secretions from the epididymis during storage. The yearly cycle of the epididymis and ductus deferens and epididymis epithelial height roughly follows the relationship shown for the presence of sperm in these structures. Males reach sexual maturity at a length of about $40 \mathrm{~cm}$ and an age of 12-21 months.

Follicles develop most rapidly from March through April. Some females probably lay their eggs in May, but most do so in June. The mean number of eggs in the right ovary of females collected in April and May was 5.8, while the mean for the left ovary was 4.8. The oviduct reaches its maximum weight in June, which is probably due to increased oviducal cellular activity in preparation for eggshell 
formation. Sperm were found in the oviducts of females from October through May indicating possible copulation at any time during that period. Females may have the capability to store sperm for seven months. Reason for sperm storage in females may have been due to: (1) low density populations, (2) aggressive encounters due to their ophiophagus nature, (3) weak sensory perception of males or inadequate pheromone production of females, or (4) small home ranges. Fat may have been used in egg development, but no relation was found between liver weight changes and fat weight changes. Females reach sexual maturity at a length of about $50 \mathrm{~cm}$ and at an estimated age of 15 months. They first lay eggs at an estimated age of 21 months and a length of about $55 \mathrm{~cm}$.

The pattern for $\underline{M}$. $\underline{f}$ tenere of prolonged breeding from late summer and early autumn to late spring and early summer followed by egg laying in mid-summer is here termed mid-aestivoquiescent.

Explanations of the phenomena observed can only be tested by controlled experiments designed to acquire precise answers to specific problems such as the function of fat reserves, growth rates, age and size at sexual maturity, epididymal function, maximum time of sperm storage, etc. 


\section{LITERATURE CITED}

Blont, R. F. 1929. Seasonal cycles of the interstitial cells in the testis of the horned toad (Phrynosoma solare). Seasonal variations in the number and morphology of the interstitial cells and the volume of the interstitial tissue. J. Morph. and Physiol. 48:317-344.

Campbe11, J. A. 1972. Reproduction in captive Trans-Pecos ratsnakes, Elaphe subocularis. Herpetol. Review $4: 129-130$.

Campbe11, J.A. 1973. A captive hatching of Micrurus fulvius tenere (Serpentes, Elapidae). J. Herpetol. 7(3):312-315.

Cieslak, E. S. 1945. Relations between the reproductive cycle and the pituitary gland in the snake Thamnophis radix. Physiol. Zool. 18;229-329.

Clark, D. R. 1964. Reproduction and sexual dimorphism in a population of rough earth snakes, Virginia striatula (Linnaeus). Texas Jour. Sci. (16)3: $\overline{265-295 .}$

Cochran, D. M. and C. J. Goin. 1970. The new field book of reptiles and amphibians. G. P. Putnam's Sons, New York.

Conant, R. 1975. A field guide to reptiles and amphibians of eastern and central North America. Houghton Mifflin Company, Boston.

Ditmars, R. L. 1936. The reptiles of North America. Doubleday and Company, Inc., Garden City.

Fitch, H. S. 1963. Natural history of the racer Coluber constrictor. Univ. Kansas Pub1. Mus. Nat. Hist. $15(8): 351-468$.

Fitch, H. S. 1970. Reproductive cycles of lizards and snakes. Univ. Kansas Mus. Nat. Hist., Misc. Publ. 52.

Fox, W. 1952. Seasonal variation in the male reproductive system of the Pacific Coast garter snakes. Jour. Morph. 90:481-553. 
Gillingham, J. C. 1976. Reproductive behavior of the rat snakes of eastern North America, genus Elaphe. Unpublished.

Goldberg, S. R. and W. S. Parker. 1975. Seasonal testicular histology of the colubrid snakes, Masticophis taeniatus and Pituophis melanoleucus. Herpetologica $31 ; \overline{317-322 .}$

Jameson, E. W. 1974. Fat and breeding cycles in a montane population of Sceloporus graciosus. J. Herpetol. 8(4): 311-322.

Licht, P., and G. C. Gorman. 1970. Reproductive and fat cycles in Caribbean Anolis lizards. Univ. California Pub1. Zool. 95:1-52.

Lofts, B., J. G. Phillips, and W. H. Tam. 1966. Seasonal changes in the testis of the cobra, Naja naja (Linn). Gen. Comp. Endocrinol. 6:466-475.

Miller, M. R. 1948. The seasonal histological changes occurring in the ovary, corpul luteum, and testis of the viviparous lizard Xantusia vigilis. Univ. Calif. Pub1. Zool. 47:197-224.

Myers, C. W. 1965. Biology of the ringneck snake, Diadophis punctatus, in Florida. Bull. Florida State Mus. 10(2):43-90.

Oliver, J. A. 1955. The natural history of North American amphibians and reptiles. D. Van Nostrand Company, Inc., Princeton, New Jersey.

Platt, D. R. 1969. Natural history of the eastern and western hognose snakes Heterodon platyrhinos and Heterodon nasicus. Univ. Kansas Publ. Mus. Nat. Hist. $\overline{18(4): 253}-\overline{420}$.

Reynolds, A. E. 1943. The normal seasonal reproductive cycle in the male Eumeces fasciatus together with some observation on the effects of castration and hormone administration. J. Morph. 72:331-375.

Risley, P. L. 1938. Seasonal changes in the testis of the musk turtle, Sternotherus odoratus. L. J. Morph. $63: 301-317$.

Sabath, M., and R. Worthington. 1959. Eggs and young of certain Texas reptiles. Herpetologica 15:31-32.

Schmidt, K. P. and D. D. Davis. 1941. Field book of snakes of the United States and Canada. G. P. Putnam's Sons, New York. 
Telford, S. R. 1955. A description of the eggs of the coral snake Micrurus f. fulvius. Copeia 1955:258.

Tinkle, D. W. 1962. Reproductive potential and cycles in female Crotalus atrox from northwestern Texas. Copeia $1962: 306-313$.

Volsфe, H. 1944. Structure and seasonal variation of the male reproductive organs of Vipera berus (L.). Spolia Zoo1. Mus. Hauniensis 5:1-172.

Werler, J. E. 1951. Miscellaneous notes on the eggs and young of Texas and Mexican reptiles. Zoologica 36:37-48.

Wharton, C. H. 1966. Reproduction and growth in cottonmouths, Agkistrodon piscivorus Lacepede, of Cedar Keys, Florida. Copeia 1966:149-161.

Wright, A. H., and A. A. Wright. 1957. Handbook of snakes of the United States and Canada. Comstock Publishing Associates, Ithica.

Zegel, J. C. 1975. Notes on collecting and breeding the eastern coral snake, Micrurus fulvius fulvius. Bull. Southeastern Herpetol. Soc, $1(\overline{6): 9-10}$. 


\author{
VITA $^{2}$ \\ Hubert Ronald Quinn \\ Candidate for the Degree of \\ Master of Science
}

Thesis: REPRODUCTION AND GROWTH OF THE TEXAS CORAL SNAKE (MICRURUS FULVIUS TENERE)

Major Field: Zoology

Biographical :

Personal Data: Born in Terre Haute, Indiana, 1 October 1946, the son of George and Helen Quinn.

Education: Received Bachelor of Science degree in biology from Indiana State University in 1968; enrolled in Master of Science program at Texas Christian University from 1974-1975; completed requirements for the Master of Science degree at Oklahoma State University in December, 1977.

Professional Experience: Biology Teacher, Paschal County Board of Public Instruction, Florida, 19681969; Biology Teacher, Dade County Board of Public Instruction, Florida, 1969-1970; Supervisor of Education, Fort Worth Zoological Park, Texas, 1970-1975; Zoological Curator, Oklahoma City Zoo, Oklahoma, 1975-1977; Teaching Assistant, Oklahoma State University, Oklahoma, 1977; Curator of Reptiles and Amphibians, Houston Zoological Park, 1977-present.

Professional Organizations: American Association of Zoological Parks and Aquariums, 1971-present; American Society of Ichthyologists and Herpetologists, 1976-present; American Society of Mammalogists, 1973-present; Herpetologists League, 1971-present; Oklahoma Herpetological Society, 1976present; Society for the Study of Amphibians and Reptiles, 1973-present; Zoo Fauna Association, 1971present. 